\title{
Pengaruh Peer Group Terhadap Adopsi Inovasi Aplikasi Tiktok
}

\author{
Kevinezra Simohartono, Rezi Erdiansyah, Sudarto \\ Kevinezrasim@gmail.co,Rezie@fikom.untar.ac.id,Antosudarto@gmail.com \\ Fakultas Ilmu Komunikasi Universitas Tarumanagara
}

\begin{abstract}
This study discusses how to change from Peer Groups (peers) to the Tiktok application that was developed through the innovation diffusion attribute. Peer groups as recipients of communication receive a significant positive in delivering messages to prospective adopters of the level of peer achievement. The phenomenon of the spread of marketing through peers in the field of communication technology has not been widely used at this time, so this phenomenon is interesting to discuss. The theory used by researchers is the diffusion theory of innovation, peer groups, and new media. This research uses quantitative analysis methodology for structural equation modeling and is processed using smart pls. The number of respondents used in this study was 100 people. Data analysis uses the validity test, reliability test, multicollinearity test. In this study, it was found that the peer group did not directly support the level of innovation adoption, but had indirect support which was moderated by the diffusion attributes of innovation namely compatibility and relative advantages
\end{abstract}

Keywords: diffusion of innovation, peer group, innovation diffusion attribute, TikTok

\begin{abstract}
Abstrak:
Penelitian ini membahas tentang bagaimana pengaruh peer group (teman sebaya) terhadap difusi inovasi aplikasi Tiktok melalui atribut difusi inovasi. Peer Group sebagai saluran komunikasi dianggap memiliki pengaruh positif yang signifikan dalam menyampaikan pesan inovasi kepada calon adopter karena tingginya tingkat kepercayaan teman sebaya. Fenomena penyebaran marketing melalui teman sebaya dalam bidang teknologi komunikasi belum banyak digunakan pada saat ini. Oleh karena itu, fenomena ini menarik untuk dibahas. Teori yang digunakan peneliti adalah teori difusi inovasi, peer group, dan media baru. Penelitian ini menggunakan pendekatan kuantitatif dengan metode teknik analisis jalur structural equation modeling dan diolah menggunakan smartpls. Jumlah responden yang digunakan dalam penelitian ini sebanyak 100 orang. Analisis data menggunakan uji validitas, uji reliabilitas, uji multikolinearitas. Dalam penelitian ini ditemukan bahwa peer group tidak berpengaruh langsung dengan tingkat adopsi inovasi, tetapi memiliki pengaruh tidak langsung yang dimoderasi oleh atribut difusi inovasi yaitu kompatibilitas dan keuntungan relative.
\end{abstract}

Kata Kunci : difusi inovasi, peer group, atribut difusi inovasi, TikTok.

\section{Pendahuluan}

Saat ini, media sosial telah menjadi trend di semua kalangan masyarakat. Media sosial (Cervia 2020) adalah sebuah media daring di mana para penggunanya dapat dengan mudah berpartisipasi, berbagi, dan menciptakan konten. Media sosial meliputi blog, jejaring sosial, wiki, forum dan dunia virtual. Blog, jejaring sosial, dan wiki merupakan bentuk media sosial yang paling umum digunakan oleh masyarakat di seluruh dunia. Media sosial sebagai "sebuah kelompok aplikasi berbasis internet yang membangun di atas dasar ideologi web 2.0, dan yang memungkinkian 
penciptaan dan pertukaran user-genereted content (Kaplan \& Haenlein, 2010)

Media sosial sendiri mempunyai beraneka ragam jenis dan fungsi. Terdapat media sosial yang digunakan penggunanya sebagai sarana informasi dan komunikasi. Media sosial tidak hanya digunakan sebagai alat untuk berkomunikasi dan berinteraksi, tetapi juga sebagai alat ekspresi diri dan pencitraan diri (Kaplan \& Haenlein, 2010). Rideout M.A. et al., (2010) menyatakan bahwa media sosial telah menjadi gaya hidup bagi kebanyakan generasi muda di seluruh dunia. Hal ini tanpa kita sadari memberi pengaruh yang besar dalam kehidupan kita. Kalangan remaja rata-rata mengakses media sosial selama 7,5 jam per sehari. Selain itu berdasarkan riset Wearesocial Hootsuite yang dirilis Januari 2019 pengguna media sosial di Indonesia mencapai 150 juta atau sebesar $56 \%$ dari total populasi.

Tiktok adalah salah satu aplikasi media sosial baru buatan negara Tiongkok yang diluncurkan pada tahun 2017 untuk pasar internasional dan pada saat ini aplikasi tersebut merupakan aplikasi yang paling banyak diunduh di Amerika Serikat dan juga aplikasi ketujuh paling banyak diunduh. Awalnya, Tiktok tidak disambut dengan baik oleh sebagian masyarakat Indonesia. Kementerian Komunikasi dan Informatika RI memperoleh laporan berupa keluhan terkait Tiktok sebanyak kurang lebih 2.853 selama bulan Juni hingga Juli 2018 hingga kemudian pemerintah memblokir aplikasi tersebut.

Kini Tiktok telah memiliki kantor cabang di Indonesia dan merupakan aplikasi yang paling digemari disamping Instagram, Facebook, dan Youtube. Keberadaan kantor cabang di Indonesia membuat Tiktok menjadi peduli dan fokus dalam pembuatan konten lokal. Strategi Tiktok saat ini adalah mentransmisi kontenkonten lokal tersebut agar menjadi semakin digemari dan menimbulkan efek domino pada masyarakat Indonesia. Hingga saat ini, konten Indonesia pun banyak digunakan dan viral oleh pengguna dari negara lain seperti Amerika Serikat

Berdasarkan uraian di atas, maka rumusan masalah dalam penelitian ini yakni bagaimana pengaruh peer group terhadap adopsi inovasi aplikasi Tiktok melalui atribut difusi inovasi pada mahasiswa Universitas Tarumanagara? Penelitian ini menggunakan teori difusi inovasi oleh Rogers yang membahas bagaimana proses di mana suatu inovasi dikomunikasikan melalui saluran tertentu dari waktu ke waktu di antara anggota sistem sosial. Dalam bukunya, Rogers (2015) menyebut lima atribut difusi inovasi yaitu: Pertama, keuntungan relatif adalah sejauh mana inovasi dianggap lebih baik daripada ide yang digantikannya. Kedua, kompatibilitas telah menyambut inovasi yang dianggap konsisten dengan nilai-nilai yang ada, pengalaman masa lalu, dan kebutuhan calon pengadopsi. Ketiga, kompleksitas telah menyambut komunikasi yang dianggap sulit untuk dipahami dan digunakan. Keempat, trialability adalah tingkat di mana suatu inovasi dapat dilakukan secara terbatas. Kelima, observability adalah sejauh mana hasil suatu inovasi dapat dilihat oleh orang lain.

Dari teori-teori yang telah diuraikan, maka terbentuklah sebuah model pemikiran dalam penelitian ini. Dapat dijabarkan bahwa yang berperan sebagai variabel independen yaitu peer group (X1), keuntungan relatif (X2), kompatibilitas (X3), kompleksitas, triabilitas(X5), observabilitas (X6). Variabel dependen yaitu adopsi (Y). Terdapat 11 hipotesis yang saling berkaitan untuk dapat melihat bagaimana hubungan antar variabel yaitu:

H1 : peer group berpengaruh secara positif dan signifikan terhadap adopsi

$\mathrm{H} 2$ : peer group menambahkan nilai kepada keuntungan relatif

H3 : peer group menambahkan nilai kepada kompatibilitas 
H4 : peer group menambahkan nilai kepada kompleksitas

H5 : peer group menambahkan nilai kepada triabilitas

H6 : peer group menambahkan nilai kepada observabilitas

H7 : semakin tinggi tingkat keuntungan relatif berpengaruh secara positif dan signifikan terhadap adopsi

H8 : semakin tinggi tingkat kompatibilitas berpengaruh secara positif dan signifikan terhadap adopsi

H9 : semakin tinggi tingkat kompleksitas berpengaruh secara negatif dan signifikan terhadap adopsi

H10 : semakin tinggi tingkat triabilitas berpengaruh secara positif dan signifikan terhadap adopsi

H1 : semakin tinggi observabilitas tingkat berpengaruh secara positif dan signifikan terhadap adopsi

\section{Metode Penelitian}

Penelitian ini menggunakan metode analisis data Partial Least Square (PLS) dengan menggunakan piranti lunak SmartPLS3 yang dijalankan dengan media komputer. PLS merupakan analisis persamaan struktural (SEM) berbasis varian yang secara simultan dapat melakukan pengujian model pengukuran sekaligus pengujian model struktural.

Pertimbangan peneliti menggunakan PLS antara lain: Pertama, PLS dapat digunakan untuk menganalisis teori yang masih dikatakan lemah, mengingat beberapa variabel baru yang peneliti masukkan belum memiliki dasar teori yang kuat. Oleh karena itu PLS dapat digunakan untuk membuat prediksi. (sudarto 2018)

Menurut Sugiyono (2008), populasi adalah wilayah generalisasi yang terdiri atas: objek/subjek yang mempunyai kualitas dan karakteristik tertentu yang ditetapkan oleh peneliti untuk dipelajari dan kemudian ditarik kesimpulannya. Dalam penelitian ini penulis memilih para individu yang aktif berkuliah di universitas Tarumanagara. Peneliti memilih menggunakan prinsip non probability sample, yaitu memberi kesempatan yang sama kepada semua elemen populasi untuk menjadi sampel. Sampel yang digunakan peneliti adalah mahasiswa aktif Universitas Tarumanagara sebanyak 100 responden.

Dalam penelitian ini, penulis ingin meneliti pengaruh dari variabel independen terhadap dependen dan juga pengaruh terhadap masing-masing variabel maka penulis menggunakan penelitian kuantitatif dengan teknik Structural Equation Modeling (SEM). Penulis menggunakan kuisioner sebagai metode pengumpulan data maka pendekatan survei yang digunakan karena dalam penelitian.

\section{Hasil Temuan dan Diskusi}

Hasil penelitian yang dilakukan dengan analisis jalur antar konstruk yang ada, ditemukan bahwa peer group (teman sebaya) tidak memiliki pengaruh positif yang signifikan terhadap adopsi. Tetapi peer group (teman sebaya) memiliki pengaruh positif yang signifikan kepada semua atribut difusi inovasi.

Dari kelima atribut difusi inovasi hanya dua yang memiliki pengaruh positif yang signifikan kepada adopsi yaitu keuntungan relatif dan kompatibilitas. Dari hal tersebut maka dapat disimpulkan bahwa peer group (teman sebaya) memiliki pengaruh positif kepada adopsi yang dimoderasi oleh kompatibilitas dan keuntungan 
relatif. Hasil tersebut peneliti dapatkan dari hasil analisis data menggunakan uji validitas, uji reliabilitas, uji multikolinearitas dan uji antar konstruk.

Dari olah data terhadap 100 responden didapatkan hasil bahwa peer group (teman sebaya) memiliki pengaruh secara tidak langsung kepada adopsi. Artinya peer group (teman sebaya) baru memiliki peran bila dimoderasi oleh atribut difusi inovasi.

Pada penelitian ini menggunakan uji antar konstruk untuk menguji hubungan antar masing-masing variabel. Standar hubungan kausalitas antar variabel yang signifikan adalah hubungan antar variabel yang memiliki nilai $P$-Value kurang dari $0.05(<5 \%)$ sebagai berikut:

a. Bila $P$-Value $<0.05$ maka ho ditolak dan ha diterima

b. Bila $P$-Value $>0.05$ maka ho diterima dan ha ditolak

Dari data yang didapatkan dari 100 responden menunjukan hasil $\mathrm{H} 1, \mathrm{H} 3$, H6,H7, H8, H9, H10 diterima karena memiliki nilai $P$-Value $<0.05$ dengan rentang $0-0,007$. Artinya peer group (teman sebaya) memiliki pengaruh signifikan kepada semua atribut difusi inovasi. Kompatibilitas, keuntungan relatif memiliki pengaruh positif terhadap adopsi. Sedangkan H2, H4, H5, H11 memiliki nilai $P$-Value $>0.05$ yaitu direntang 0,145 - 0,809.

Data selanjutnya yang diuji antar konstruk secara tidak langsung yang memiliki pengaruh yaitu:

a. PEER GROUP - KOMPATIBILITAS - ADOPSI dengan nilai P-Value 0,007

b. PEER GROUP - KEUNTUNGAN RELATIF - ADOPSI dengan nilai P-Value 0,001

Artinya peer group (teman sebaya) baru memiliki peran bila dimoderasi oleh atribut difusi inovasi.

Berdasarkan analisis jalur yang telah dipaparkan di atas, dapat diketahui bahwa variabel peer group akan menjadi signifikan bila dimoderasi oleh 2 variabel atribut inovasi yang signifikan tersebut (keuntungan relatif dan kompatibilitas). Mengapa tiga dari dua atribut inovasi difusi tidak menjadi signifikan secara positif mungkin dikarenakan peer group tidak mengkomunikasikan secara positif dengan baik ketiga atribut inovasi difusi lainya.

Dari keterangan yang sudah disampaikan pada bab sebelumnya dapat dilihat bahwa variabel peer group tidak memiliki pengaruh langsung yang signifikan kepada variabel Adopsi. Namun peneliti menemukan bahwa ada 2 variabel yang memiliki pengaruh langsung yang signifikan yaitu variabel Keuntungan Relatif dan variabel Kompatibilitas. Tidak heran bila Keuntungan Relatif menjadi variabel yang signifikan terhadap variabel adopsi. Rogers (2015) menyebutkan bahwa difusi suatu inovasi adalah proses pengurangan ketidakpastian. Ketika individu melewati proses keputusan-inovasi, mereka termotivasi untuk mencari informasi untuk mengurangi ketidakpastian tentang keunggulan relatif dari suatu inovasi.

Pada variabel kompatibilitas, Tiktok didukung dengan kesamaan pada nilai ide-ide sebelumnya yang sudah ada seperti mengambil video dan membagikannya. Praktik seperti ini sudah digemari oleh masyarakat. Rogers (2015) menyatakan bahwa kecocokan suatu inovasi dengan ide sebelumnya dapat mempercepat atau memperlambat laju adopsi. Gagasan lama adalah alat utama untuk menilai gagasan baru. Praktik sebelumnya adalah standar yang biasa digunakan untuk menafsirkan inovasi, sehingga mengurangi ketidakpastian untuk keputusan adopsi.

\section{Kesimpulan}


Peer Group tidak memiliki pengaruh langsung yang signifikan terhadap keputusan positif adopsi. Aspek atribut inovasi seperti kompleksitas, triabilitas dan observabilitas tidak berpengaruh langsung secara signifikan terhadap keputusan positif adopsi. Hal ini dikarenakan peer group tidak mengkomunikasikan secara positif dengan baik ketiga atribut inovasi difusi tersebut.

Berdasarkan hasil penelitian yang dilakukan peneliti dapat diketahui bahwa Kompatibilitas dan Keuntungan Relatif memiliki pengaruh langsung yang signifikan terhadap keputusan positif adopsi. Hal ini dapat dikarenakan peer group mengkomunikasikan kedua atribut inovasi difusi tersebut dengan baik sehingga individu dapat mencerna informasi dengan baik.

Berdasarkan dua kesimpulan di atas maka variabel peer group tetap memiliki pengaruh kepada tingkat adopsi dari aplikasi Tiktok secara tidak langsung yang dimoderasi oleh dua variabel atribut inovasi yaitu kompatibilitas dan keuntungan relatif.

\section{Ucapan Terimakasih}

Pada kesempatan ini penulis mengucap syukur dan terima kasih kepada Tuhan Yang Maha Esa karena atas rahmat-Nya penelitian ini dapat terselesaikan. Peneliti juga ingin mengucapkan terima seluruh teman-teman yang telah memberikan dukungan moril ataupun materil kepada peneliti sehingga peneliti dapat menyelesaikan jurnal ini sesuai dengan yang diharapkan.

\section{Daftar Pustaka:}

Ferdiana, Cervia. (2020). Penggunaan Media Sosial Tinder dan Fenomena Pergaulan Bebas Di Indonesia

Kaplan, A. M., \& Haenlein, M. (2010). Kaplan, A. M., \& Haenlein, M. (2010). Users of the world, unite! The challenges and opportunities of Social Media. Business Horizons. https://doi.org/10.1109/WCNC.2006.1683604

Rideout M.A., V. J., Foehr Ph.D., U. G., \& Roberts Ph.D., D. F. (2010). Generation M2: Media in the Lives of 8 to 18 Year-Olds. The Henry J. Kaiser Family Foundation. https://doi.org/P0-446179799-1366925520306

Rogers, E. M. (2015). Evolution: Diffusion of Innovations. In International Encyclopedia of the Social \& Behavioral Sciences: Second Edition. https://doi.org/10.1016/B978-0-08-097086-8.81064-8

Sugiyono. (2010). Metode Penelitian Kuantitatif, kualitatif, dan R\&D. Bandung:Alfabeta.

Sudarto (2018). Proses Difusi Berita Politik dan Pembentukan Opini Publik Di Era Media Sosial 